\title{
QUALITY OF ONE STOP SERVICE SERVICE TO SATISFACTION AND ITS IMPACT ON INSTITUTIONAL IMAGE (Survey at the Immigration Office Class II Tasikmalaya)
}

\author{
Sri Mulyati ${ }^{1}$, Hasan Fahmi Kusnandar ${ }^{2}$ \\ ${ }^{1}$ email: hasanfahmi2kusnandar@gmail.com \\ ${ }^{1,2}$ Politeknik Triguna Tasikmalaya
}

\begin{abstract}
Abstrak
Tujuan penelitian ini adalah untuk mengetahui dan menganalisis Pengaruh Kualitas Pelayanan One Stop Service Terhadap Kepuasan Pemohon Pembuatan Surat Perjalanan Republik Indonesia Dan Dampaknya Pada Citra Institusi di Kantor Imigrasi Kelas II Tasikmalaya. Metode penelitian yang digunakan adalah metode survey. Pengumpulan data diperoleh melalui kuoesioner dan studi pustaka. Populasi dalam penelitian ini adalah pemohon paspor di Kantor Imigrasi Kelas II Tasikmalaya. Penentuan sampel berdasarkan jumlah pemohon paspor yaitu 100 orang. Analisis yang digunakan adalah analisis jalur. Hasil penelitian menemukan bahwa secara parsial dan simultan Kualitas Pelayanan One Stop Service, berpengaruh terhadap Kepuasan Pemohon dalam pembuatan Surat Perjalanan Republik Indonesia dan berdampak terhadap Citra Institusi di Kantor Imigrasi Kelas II Tasikmalaya.
\end{abstract}

Kata Kunci : Kualitas Pelayanan, Kepuasan Pemohon, citra Institusi

\begin{abstract}
The objective of this research is to identify and analyze The Effect of "One Stop Service"Quality Toward Applicant's Satisfaction in Making Republic of Indonesia's Travel Documents and Its Effect Toward The Image of Tasikmalaya Immigration Office - Class Two Institution. The data collection was obtained through questionnaire and literature. The population in this research was Passport Applicants who applied in Tasikmalaya Immigration Office-Class Two. The samples were determined based on 100 passport applicants. Metodology used was path analysis. In partially and simultanously, the result of research shows that "One Stop Service" has impact toward applicant's satisfaction in making The Republic of Indonesia's travel documents, and also has impact toward the impression of Tasikmalaya Immigration Office - Class Two.
\end{abstract}

Keywords: Quality of service, customer satisfaction, image of institution.

\section{PENDAHULUAN}

Standar Pelayanan adalah tolok ukur yang dipergunakan sebagai pedoman penyelenggaraan pelayanan dan acuan penilaian kualitas pelayanan sebagai kewajiban dan janji penyelenggara kepada masyarakat dalam rangka pelayanan yang berkualitas, cepat, mudah, terjangkau, dan terukur. Paradigma penyelenggaraan pelayanan instansi pemerintah telah terjadi pergeseran 
paradigma dari paradigma penguasa menjadi pelayan dalam menyelenggarakan pelayanan publik. Penyelenggaraan pelayanan publik merupakan upaya negara untuk memenuhi kebutuhan dasar dan hak-hak sipil setiap warga negara atas barang/jasa dan pelayanan administrasi yang di sediakan oleh penyelenggara pelayanan publik. (Surijadi dalam Jurnal Administrasi Publik dan Birokrasi, 2012:7), mengatakan meskipun upaya tersebut telah dilakukan oleh pemerintah, namun realitas pelayanan publik belum juga menunjukkan perubahan yang signifikan. Pelayanan publik dimaksudkan untuk mensejahterakan masyarakat. Menurut Ratminto dan Winarsih (2012:5) mendefinisikan pelayanan publik sebagai segala bentuk jasa pelayanan, baik dalam bentuk barang publik maupun dalam bentuk jasa publik yang pada prinsipnya menjadi tanggung jawab dan dilaksanakan oleh instansi pemerintah di pusat, daerah, dan dilingkungan badan usaha milik negara atau badan usaha milik daerah, dalam rangka upaya pemenuhan kebutuhan masyarakat maupun dalam rangka ketentuan peraturan perundang-undangan. Pelayanan publik yang berkualitas juga dapat dilihat dari seberapa besar dimensi kualitas pelayanan, seperti reliability, responsivity, assurance, tangibility dan emphaty dapat diwujudkan oleh organisasi pelayanan (Parasuraman dalam Tjiptono 2005:273). Citra instansi yang baik akan mempengaruhi pikiran masyarakat akan mendapatkan pelayanan yang bermutu dan berkualitas, Menurut Kotler (2007 : 388) mendefinisikan citra / image sebagai seperangkat keyakinan, ide dan kesan yang dimiliki seseorang terhadap suatu objek dimana sikap dan objek tindakan seseorang terhadap suatu objek sangat dikondisikan oleh citra objek tersebut. Jika masyarakat luas memiliki persepsi yang positif terhadap citra atau nama baik penyelenggara pelayanan publik, maka kepercayaan masyarakat terhadap penyelenggara pelayanan publik juga akan terbentuk. Citra instansi yang baik akan mempengaruhi pikiran masyarakat akan mendapatkan pelayanan yang bermutu dan berkualitas, Menurut Kotler (2007 : 388) mendefinisikan citra / image sebagai seperangkat keyakinan, ide dan kesan yang dimiliki seseorang terhadap suatu objek dimana sikap dan objek tindakan seseorang terhadap suatu objek sangat dikondisikan oleh citra objek tersebut. Jika masyarakat luas memiliki persepsi yang positif terhadap citra atau nama baik penyelenggara pelayanan publik, maka kepercayaan masyarakat terhadap penyelenggara pelayanan publik juga akan terbentuk. Adapun hasil yang diharapkan dari penerapan kebijakan ini adalah :

a. Memberikan kepastian waktu, yaitu pelaksanaan paspor dapat diselesaikan dalam kurun waktu yang tepat dan cepat;

b. Menghilangkan prosedur yang berbelit-belit

c. Menghilangkan calo dan praktek pungutan liar

d. Mengurangi panjangnya birokrasi dalam pengurusan paspor itu sendiri;

e. Mewujudkan transparansi dan akuntabilitas pelayanan Paspor R.I

Dalam konsep manajemen pemasaran jasa, kepuasan pelanggan dapat dicapai apabila produk pelayanan yang diberikan oleh penyedia pelayanan memenuhi kualitas yang diharapkan masyarakat. Oleh karena itu, survei kepuasan pelanggan memiliki arti penting dalam upaya peningkatan pelayanan publik. Upaya Kantor Imigrasi Kelas II Tasikmalaya untuk dapat memenuhi kualitas pelayanan yang diharapkan masyarakat salah satunya 
adalah membangun sistem pengelolaan Indeks Kepuasan Masyarakat (IKM).

Berdasakan latar belakang permasalah diatas, maka identifikasi masalah dalam penelitian ini adalah sebegai berikut: Bagaimana pengaruh secara parsial dan simultan Kualitas Pelayanan One Stop Service, dan Kepuasan Pemohon dalam pembuatan Surat Perjalanan Republik Indonesia terhadap pada Citra Institusi di Kantor Imigrasi Kelas II Tasikmalaya?

\section{KAJIAN PUSTAKA}

\section{a. Pengertian Pelayanan Publik}

Pelayanan adalah suatu aktivitas atau serangkaian aktivitas yang bersifat tidak kasat mata (tidak dapat diraba) yang terjadi sebagai akibat adanya interaksi antara konsumen dengan karyawan atau hal-hal lain yang disediakan oleh perusahaan pemberi pelayanan yang dimaksudkan untuk memecahkan permasalahan konsumen/pelanggan. Gronroos (1990:27) dalam (Ratminto \& Winarsih, 2005:2). Undang-Undang No. 25 Tahun 2009 tentang Pelayanan Publik mendefinisikan pelayanan publik sebagai berikut: Pelayanan publik adalah kegiatan atau rangkaian kegiatan dalam rangka pemenuhan kebutuhan pelayanan sesuai dengan peraturan perundang-undangan bagi setiap warga negara dan penduduk atas barang, jasa, dan/atau pelayanan administratif yang disediakan oleh penyelenggara pelayanan publik. Pelayanan publik (public service) adalah suatu pelayanan atau pemberian terhadap masyarakat yang berupa penggunaan fasilitas -fasilitas umum, baik jasa maupun non jasa, yang dilakukan oleh organisasi publik dalam hal ini suatu pemerintahan. Dalam pemerintahan pihak yang memberikan pelayanan adalah aparatur pemerintahan beserta segenap kelengkapan kelembagannya (Ahmad Ainur Rohman,2010:3). Moenir (2000) mengemukakan bahwa pelayanan itu adalah (jurnal ilmu administrasi 2, 2008:138) :

1. Adanya kemudahan dalam pengurusan kepentingan yakni pelayanan yang cepat dalam arti tanpa hambatan.

2. Memperoleh pelayanan secara wajar, yaitu pelayanan tanpa disertai kata-kata yang bernada meminta sesuatu kepada pihak yang dilayani dengan alasan apapun.

3. Memperoleh perlakuan yang sama dalam pelayanan, yaitu tanpa pilih kasih dimana aturan dan prosedur diterapkan sama.

4. Memperoleh perlakuan yang jujur dan terus terang. Ini menyangkut keterbukaan pihak yang melayani, seperti jika ada masalah yang dihadapi dalam pemberian pelayanan sebaiknya dikemukakan terus terang.

\section{b. Pengertian Kualitas Pelayanan}

Menurut Wyckof dalam Tjiptono (2005: 260) berpendapat bahwa Kualitas jasa merupakan tingkat keunggulan (exellence) yang diharapkan dalam pengendalian atas keunggulan tersebut untuk memenuhi keinginan pelanggan. Dengan kata lain, terdapat dua faktor utama yang mempengaruhi kualitas jasa yakni, jasa yang diharapkan (expected service) dan jasa yang dipersepsikan 
(perceived service). Jika layanan yang diharapkan pelanggan melebihi harapannya, maka persepsi akan positif, sebaliknya jika layanan tidak sesuai dengan persepsi pelanggan maka persepsi kualitas menjadi rendah (negatif).(jurnal ilmu administrasi 2, 2008:139). Pada dasarnya, terdapat beragam alat ukur, tolok ukur, parameter, atau indikator kualitas layanan publik karena pihak yang menentukan kualitas beragam, berikut sudut pandangnya. Secara sederhana dapat dikatakan kualitas pelayanan dapat diketahui dengan cara membandingkan persepsi pelanggan atas pelayanan yang nyata-nyata mereka terima atau peroleh dengan pelayanan yang sesungguhnya mereka harapkan atau inginkan. Jika kenyataan lebih dari yang diharapkan, maka pelayanan dapat dikatakan bermutu. Sedangkan jika kenyataannya kurang dari yang diharapkan, maka pelayanan dapat dikatakan tidak bermutu. Apabila kenyataan sama dengan harapan maka pelayanan tersebut memuaskan. dalam Ratminto \& Septi Winarsih (2005:175), mengatakan bahwa kualitas pelayanan (jasa) dikelompokkan ke dalam 5 dimensi oleh Parasuraman, Berry dan Zethaml,yaitu :

a. Bukti Langsung (Tangible), yaitu : sebagai fasilitas yang dapat dilihat dan di gunakan perusahaan dalam upaya memenuhi kepuasan pelanggan, seperti gedung kantor, peralatan kantor, penampilan karyawan dan lain lain.

b. Kehandalan(Reliability), yaitu : kemampuan memberikan pelayanan kepada pelanggan sesuai dengan yang di harapkan, seperti kemampuan dalam menempati janji, kemampuan memecahkan masalah dan kemampuan untuk meminimumkan kesalahan.

c. Daya Tanggap (Responsiveness), yaitu sebagai sikap tanggap, mau mendengarkan dan merespon pelanggan dalam upaya memuaskan pelanggan, misalnya : mampu memberikan informasi secara benar dan tepat, tidak menunjukan sikap sok sibuk dan mampu memberikan pertolongan dengan segera.

d. Jaminan (Assurance), yaitu :kemampuan karyawan dalam menimbulkan kepercayaan dan keyakinan pelanggan melalui pengetahuan, kesopanan serta menghargai perasaan pelanggan.

e. Kepedulian/Empati (Emphaty), yaitu : kemampuan atau kesediaan karyawan memberikan perhatian yang bersifat pribadi, seperti bersikap ramah, memahami kebutuhan dan peduli kepada pelanggannya.

\section{c. Pengertian Kepuasan Pelanggan ( Kepuasan Pemohon )}

Menurut bahasa kepuasan adalah rasa senang karena hasrat hatinya sudah terpenuhi. Sedangkan menurut Prasetyo Adi (2008:21) "kepuasan ataupun ketidakpuasan merupakan sesuatu dari pengalaman yang diterimanya dan hasil perbandingan antara pengalaman dengan apa yang diharapkan." Walaupun dalam hasanah kepustakaan terdapat banyak definisi tentang hal ini, namun pada hakekatnya kepuasan pelanggan merupakan hasil perbandingan antara apa yang dialami dengan apa yang diharapkan.

Fandy Tjiptono (2002:126) menyatakan bahwa kepuasan masyarakat merupakan evaluasi purna beli dimana alternatif yang dipilih sekurang-kurangnya sama atau melampaui harapan masyarakat, Kepuasan masyarakat adalah suatu tingkat perasaan masyarakat yang timbul sebagai akibat dari Pelayanan layanan 
servis yang diperolehnya setelah masyarakat membandingkannya dengan apa yang diharapkannya. Berdasarkan prinsip pelayanan sebagaimana telah ditetapkan dalam keputusan Menteri Pendayagunaan Aparatur Negara Nomor: KEP/25/M.PAN/2004. Yang kemudian dikembangkan menjadi 14 unsur yang relevan, valid dan realible, sebagai unsur yang minimal yang harus ada untuk dasar pengukuran indeks kepuasan masyarakat sebagai berikut :

1. Prosedur pelayanan yaitu kemudahan tahapan pelayanan yang diberikan kepada masyarakat dilihat dari sisi kesederhanaan alur pelayanan.

2. Persyaratan pelayanan yaitu persyaratan teknis dan administratif yang diperlukan untuk mendapatkan pelayanan sesuai dengan jenis pelayanannya.

3. Kejelasan petugas pelayanan yaitu keberadaan dan kepastian petugas yang memberikan pelayanan ( nama jabatan serta kewenangan dan tanggung jawabnya )

4. Kedisiplinan petugas pelayanan yaitu kesungguhan petugas dalam memberikan pelayanan terutama terhadap konsistensi waktu kerja sesuai ketentuan yang berlaku.

5. Tanggung jawab petugas pelayanan yaitu kejelasan wewenang dan tanggung jawab petugas dalam penyelenggaraan dan penyelesaian pelayanan.

6. Kemampuan petugas pelayanan yaitu tingkat keahlian dan keterampilan yang dimiliki petugas dalam memberikan/menyelesaikan pelayanan kepada masyarakat.

7. Kecepatan pelayanan yaitu target waktu pelayanan dapat diselesaikan dalam waktu yang telah ditetntukan oleh unit penyelenggara layanan.

8. Keadilan mendapatkan pelayanan dengan tidak membedakan golongan/status masyarakat yang dilayani.

9. Kesopanan dan keramahan petugas yaitu sikap dan perilaku petugas dalam memberikan pelayanan kepada masyarakat secara sopan dan ramah serta saling menghargai dan menghormati.

10. Kewajaran biaya pelayanan yaitu keterjangkauan masyarakat terhadap besarnya biaya yang ditetapkan oleh unit pelayanan

11. Kepastian biaya pelayanan yaitu kesesuaian antara biaya yang dibayarkan dengan biaya yang telah ditetapkan.

12. Kepastian jadwal pelayanan yaitu pelaksanaan waktu pelayanan sesuai ketentuan yang telah ditetapkan.

13. Kenyamanan lingkungan yaitu kondisi sarana dan prasarana yang bersih dan rapi dan teratur sehinggga memberikan rasa nyaman kepada penerima layanan.

14. Keamanan pelayanan yaitu terjaminnya tingkat keamananan lingkungan unit penyelenggara pelayanan ataupun sarana yang digunakan. Sehingga masyarakat merasa tenang untuk mendapatkan pelayanan terhadap resikoresiko yang diakibatkan dari pelaksanaan pelayanan.

\section{d. Pengertian Citra Perusahaan}

Berikut ini merupakan pengertian dari citra perusahaan menurut beberapa ahli, yaitu : Menurut Kotler yang dialih bahasakan oleh Benyamin Molan (2007:94), "citra perusahaan digambarkan sebagai kesan keseluruhan yang dibuat dalam 
pikiran masyarakat tentang suatu organisasi”. Kasali (2003:30) menjelaskan bahwa :

"Citra perusahaan yang baik dimaksudkan agar perusahaan dapat tetap hidup dan orang orang didalamnya terus mengembangkan kreativitas bahkan memberi manfaat lebih bagi orang lain". Shirley Harrison (2007:71) mengemukakan coorporate image is a valuable asset that companies need to manage. Menurut Ardianto Soemirat, (2004:22 ) ada empat indikator atau komponen dalam citra yaitu :

1. Persepsi adalah hasil pengamatan terhadap unsur lingkungan yang dikaitkan dengan satu proses pemaknaan. Dengan kata lain individu akan memberikan makna terhadap rangsangan berdasarkan pengalamanya mengenai rangsangan.

2. Kognisi adalah suatu keyakinan diri dari individu terhadap stimulus. Keyakinan ini akan timbul apabila individu telah mengerti rangsangan tersebut sehingga individu harus memberikan informasi yang cukuo untuk dapat mempengaruhi perkembangan kognisinya.

3. Motif adalah keadaan dalam pribadi seseorang yang mendorong keinginan individu untuk melakkukan kegiatan-kegiatan tertentu guna mencapai satu tujuan.

4. Sikap adalah kecenderungan bertindak, berpersepsi berfikir dan merasakan dalammenghadapi ide, objek, situasi atau nilai. Sikap bukan perilaku tetapi kecenderungan untuk berperilaku dengan cara-cara tertentu.

\section{METODE PENELITIAN}

Metode penelitian ini pada dasarnya merupakan cara ilmiah untuk mendapatkan data dan tujuan serta kegunaan tertentu. Metode penelitian merupakan cara yang digunakan peneliti untuk memperoleh, menyusun, menganalisadan menginterprestasikan data yang sedang diteliti. Penelitian ini termasuk dalam kategori penelitian verifikatif. Sifat verifikatif pada dasarnya ingin menguji kebenaran dari suatu hipotesis yang dilaksanakan melalui pengumpulan data di lapangan, dimana dalam penelitian ini penelitian verifikatif bertujuan untuk mengetahui Pengaruh Kualitas Pelayanan One Stop Service Terhadap Kepuasan Pemohon Pembuatan Surat Perjalanan Republik Indonesia dan Dampaknya Pada Citra Institusi Di Kantor Imigrasi Kelas II Tasikmalaya. Dalam mengumpulkan dan menganalisa suatu data dimulai dengan menentukan populasi terlebih dahulu. Populasi dalam penelitian ini adalah seluruh pemohon paspor di Kantor Imigrasi Kelas II Tasikmalaya sebanyak 22.863 orang. Pengambilan sampel diambil secara simple random sampling yaitu pengambilan sampel dari anggota populasi dilakukan secara acak tanpa memperhatikan strata yang ada dalam populasi itu dan didapat sebanyak 100 orang.Namundengan adanya pembulatan sampel dan penambahan sampel agar setiap terwakili maka jumlah sampel yang diteliti sebanyak 100 pemohon pembuatan paspor.

Berdasarkan judul dari penelitian ini yaitu Pengaruh Kualitas Pelayanan One Stop Service Terhadap Kepuasan Pemohon Pembuatan Surat Perjalanan 
Republik Indonesia Dan Dampaknya Pada Citra Institusi Di Kantor Imigrasi Kelas II Tasikmalaya. Maka penulis mengungkapkan beberapa penelitian variabel yang dioperasionalkan yaitu sebagai berikut :

1. Variabel Independen $(\mathrm{X})$

Yaitu variabel yang keberadaannya tidak dipengaruhi dan tidak tergantung kepada variabel lain atau variabel yang berdiri sendiri. Variabel independen dalam penelitian ini adalah Kualitas Pelayanan (X1) dan Kepuasan Pemohon (X2)

2. Variabel Dependen (Y)

Yaitu suatu variabel terkait atau tidak bebas dengan kata lain variabel yang dipengaruhi oleh variabel independen atau variabel lain. Adapun yang berfungsi sebagai variabeldependen dalam penelitian ini adalah Citra Institusi (Y) Rancangan operasionalisasi variabel ini, yang meliputi variabel, konsep variabel, sub variabel, indikator, skala pengukuran serta sumber data didasarkan atas grand theory

Mengacu kepada landasan teori dan kerangka pemikiran dalam gambar yang menghubungkan keterkaitan antara variabel. Maka analisis yang digunakan dalam penelitian ini adalah :

a. Koefisien Determinasi

Yaitu pengkuadratan koefisien korelasi $\left(\mathrm{r}^{2}\right)$ digunakan untuk menentukan besarnya pengaruh variable indpenden terhadap variable dependen.

b. Pengujian Hipotesis

Adapun pengujian hipotesis penelitian yang akan penulis lakukan dengan prosedur sebagai berikut: Hipotesis nol adalah hipotesis yang menyatakan pengaruh $\mathrm{X}$ tidak signifikan terhadap $\mathrm{Y}$, sedangkan hipotesis alternative merupakan hipotesis penelitian dari peneliti yaitu prediksi yang diturunkan dari teori yang sedang diuji. Untuk mengetahui hipotesis ditolak atau tidak, maka dibandingkan antara nilai dari t hitung dan tabel, mengikuti criteria sebagai berikut :

Kesimpulan: Menyimpulkan $\mathrm{H}_{0}$ diterima atau ditolak sesuai dengan kaidah keputusan.

\section{a. Path Analysis}

Mengacu kepada landasan teori dan kerangka pemikiran dalam gambar yang menghubungkan keterkaitan antara variabel X, dan Y. Maka analisis yang digunakan dalam penelitian ini adalah path analysis. Dengan analisis ini dapat dilihat besarnya koefisien jalur antara variable bebas X1 dan X2 dengan variable terikat Y Persamaan struktural yang menggambarkan hipotesis adalah:

$$
\begin{aligned}
& \mathrm{Y}=\mathrm{p}_{\mathrm{yx} 1} \mathrm{X} 1+\mathrm{p}_{\mathrm{yx} 2} \mathrm{X} 2+\mathrm{p}_{\mathrm{y}} \varepsilon_{1} \\
& \mathrm{Z}=\mathrm{p}_{\mathrm{zx} 1} \mathrm{X} 1+\mathrm{p}_{\mathrm{zx} 2} \mathrm{X} 2+\mathrm{z}_{\mathrm{y}} \mathrm{Y}+\mathrm{p}_{\mathrm{z}} \varepsilon_{2}
\end{aligned}
$$

Berdasarkan data yang sudah tersusun, tahap selanjutnya menentukan jumlah skor untuk masing-masing variabel, karena skor merupakan data yang terbentuk ordinal, untuk keperluan perhitungan selanjutnya data tersebut perlu ditransformasikan kedalam bentuk data interval dengan menggunakan metode successive interval. Setelah itu, nilai-nilai skor untuk variable dan tahap terakhir dilakukan penghitungan analisis jalur (path analysis). Pengaruh keterkaitan antar variable dapat dilihat dalam Gambar tersebut menyatakan bahwa diagram jalur 
tersebut hanya terdiri dari sebuah substruktur yang juga merupakan struktur lengkapnya, yang berisi tiga buah variabel eksogen $(\mathrm{X} 1, \mathrm{X} 2$, ) dan sebuah variabel endogen (Y)

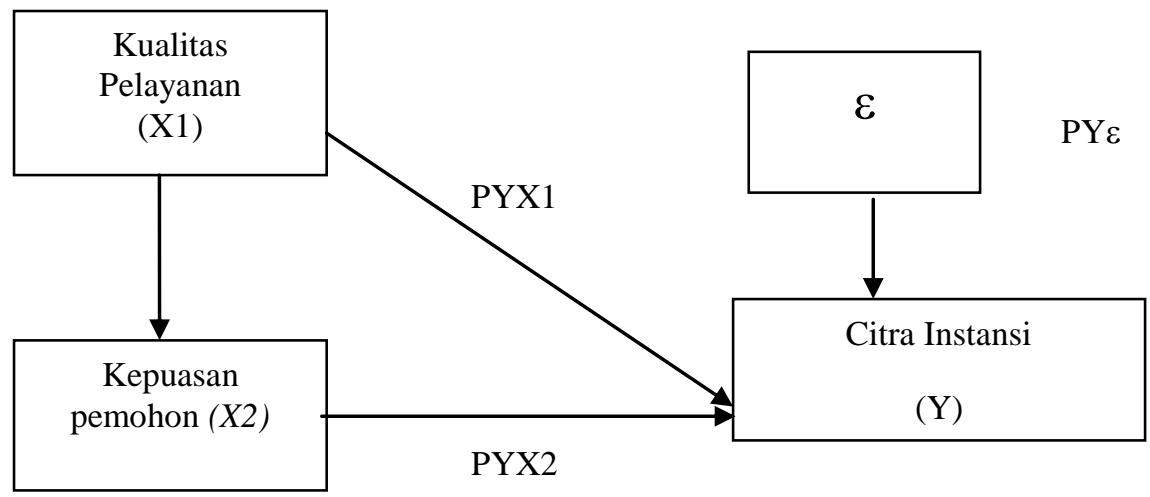

Gambar 1

Hubungan Struktural antara Variabel X1, X2, terhadap Y.

\section{d. Uji Serempak ( Uji F)}

Langkah-langkah pengujian hipotesis yaitu :

Ho $=\mathrm{pX} 1 \mathrm{Y}=\mathrm{pX} 2 \mathrm{Y}=0$ artinya secara simultan kualitas pelayanan one stop service, kepuasan pemohon tidak berpengaruh terhadap citra institusi di Kantor Imigrasi Kelas II Tasikmalaya.

$\mathrm{H} \alpha=$ Sekurang-kurangnya ada sebuah $\mathrm{pX} 1 \mathrm{Y}, \mathrm{pX} 2 \mathrm{Y} \neq 0$ secara simultan kualitas pelayanan one stop service, kepuasan pemohon berpengaruh positif terhadap citra institusi di Kantor Imigrasi Kelas II Tasikmalaya.

\section{HASIL DAN PEMBAHASAN}

Hasil pengolahan data dapat diketahui pengaruh secara parsial dan simultan kualitas pelayanan dan kepuasan terhadap Citra Institusi Kantor Imigrasi Kelas II Tasikmalaya berikut ini:

1. Pengaruh secara parsial kualitas pelayanan terhadap citra institusi Kantor Imigrasi Kelas II Tasikmalaya

Pengaruh secara parsial kualitas pelayanan terhadap Citra institusi atau $\rho \mathrm{YX}_{1}$ sebesar 0,177 . Untuk pengujian hipotesis secara parsial pengaruh kualitas pelayanan (X1) terhadap citra institusi (Y) dengan kriteria penolakan Ho jika $t_{\text {hitung }}>t_{\text {tabel }}$. Hasil penghitunganSPSS diperoleh $t_{\text {hitung }}$ $=1,560$ sedangkan $\mathrm{t}$ tabel sebesar 1,66 dengan demikian $\mathrm{t}$ hitung $<\mathrm{t}$ table sehingga dapat dikatakan bahwa tidak ada pengaruh kualitas pelayanan terhadap citra institusi.

2. Pengaruh secara parsial kepuasan pemohon terhadap citra institusi di Kantor Imigrasi Kelas II Tasikmalaya

Pengaruh secara parsial kepuasan terhadap Citra institusi atau $\rho \mathrm{YX}_{2}$ sebesar 0,518. Untuk pengujian hipotesis secara parsial pengaruh kepuasan (X2) terhadap citra institusi (Y) dengan kriteria penolakan Ho jika $t_{\text {hitung }}>t_{\text {tabel }}$. HasilpenghitunganSPSS diperoleh $t_{\text {hitung }}=4,557$ sedangkan $t$ tabel sebesar 
1,66 dengan demikian $\mathrm{t}$ hitung $>\mathrm{t}$ table sehingga dapat dikatakan bahwa terdapat pengaruh positif kepuasan terhadap citra institusi.

3. Pengaruh secara simultan kualitas pelayanan dan kepuasan terhadap citra institusi

Besarnya pengaruh secara simultan kualitas pelayanan (X1), dan kepuasan (X2) terhadap citra institusi (Y)dapat dilihat dari indikator yang digunakan masing-masing variabel dengan menggunakan path analysis diperoleh hasil $\rho^{2} \mathrm{yx}_{1} \mathrm{x}_{2}$ sebesar 0,396 atau $39,6 \%$ artinya jika kualitas pelayanan, dan kepuasan secara bersama-sama meningkat akan memberikan dampak positif, maka citra institusi juga akan meningkat. Untuk pengujian hipotesis secara simultan dengan perumusan hipotesis sebagai berikut:

Ho $: \rho \mathrm{YX}_{1}=0$

Ha $\quad: \rho \mathrm{YX}_{\mathrm{i}}=$ sekurang-kurangnya ada sebuah $\rho \mathrm{YX}_{\mathrm{i}} \neq 0$ Statistik yang digunakan adalah :

$F=\frac{(n-k-1) R_{y\left(x_{1} x_{2} x_{3}\right)}^{2}}{k\left(1-R_{Y}^{2}\right)}$

Statistik uji di atas mengikuti distribusi $\mathrm{F}$ - snedecor dengan derajat bebas $\mathrm{V}_{1}=\mathrm{k}$ dan $\mathrm{V}_{2}=\mathrm{N}-\mathrm{K}-1$. Dengan kriteria penolakan Ho jika $F_{\text {hitung }}>\mathrm{F}_{\text {tabel. }}$. Hasil perhitungan SPSS diperoleh nilai $\mathrm{F}$ hitung sebesar 37,384, sedangkan $\mathrm{F}$ table dengan taraf signifikan $\alpha$ sebesar 5\% maka dari table distribusi $\mathrm{F}$ snedecor dengan derajat bebas $\mathrm{V}_{1}=\mathrm{k}$ dan $\mathrm{V}_{2}=\mathrm{N}-\mathrm{K}-1=124-3-1$ sebesar 2,69 yang berarti $F_{\text {hitung }}$ sebesar 37,384> $F_{\text {tabel }}$ 2,69 sehingga dapat disimpulkan bahwa terdapat pengaruh positif kualitas pelayanan, dan kepuasan terhadap citra institusi.

Secara lengkap pengaruh antara variabel kualitas pelayanan (X1), dan kepuasan (X2) terhadap citra institusi (Y) dapat dilihat sebagai berikut:

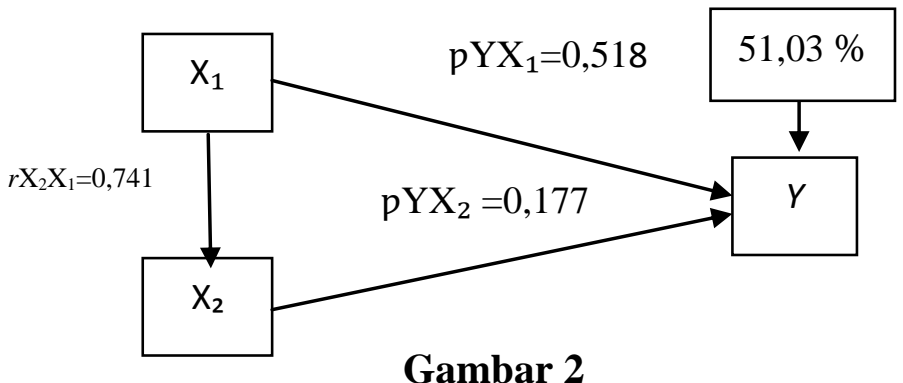

Nilai Koefisien Jalur Antara Variabel X1, X2 dan Y

Berdasarkan Gambar 4.1 di atas dapat dilihat pengaruh langsung dan tidak langsung antara variabel yaitu: 
Tabel 4 :Pengaruh Variabel $X_{1}, X_{2}$, dan $X_{3}$ Terhadap $Y$

\begin{tabular}{|c|c|}
\hline Keterangan & Nilai \\
\hline Pengaruh Kualitas Pelayanan $\left(\mathbf{X}_{1}\right)$ & \\
\hline Pengaruh langsung $X_{1}$ Terhadap $Y=\rho Y X 1$. $\rho Y X 1$ & 0.683 \\
\hline $\begin{array}{c}\text { Pengaruh tidak langsung } X_{1} \text { Terhadap } Y \text { melalui } X_{2}= \\
\rho Y X 1 \text {.rX1X2 . } \rho Y X 2+\rho Y X 2 \text {.rX1X2 }\end{array}$ & 0.1901 \\
\hline $\begin{array}{l}\text { Pengaruh Total } X_{1} \text { terhadap } \\
Y\end{array}$ & $\mathbf{0 . 4 5 8 4}$ \\
\hline \multicolumn{2}{|l|}{ Pengaruh Kepuasan pemohon $\left(\mathbf{X}_{2}\right)$} \\
\hline$\rho Y X 2$ Pengaruh langsung $X_{2}$ Terhadap $Y=\rho Y X 2$. & 0.0313 \\
\hline Pengaruh total $\left(\mathrm{X}_{2}\right)$ terhadap $\mathrm{Y}$ & 0.0313 \\
\hline Pengaruh Total X1, X2, secara simultan terhadap Y & 0.4897 \\
\hline Pengaruh Variabel lain yang tidak diteliti & 0.5103 \\
\hline
\end{tabular}

Berdasarkan hasil perhitungan diatas menunjukkan secara keseluruhan variabel kualitas pelayanan (X1), dan kepuasan (X2) mempunyai pengaruh terhadap citra institusi (Y) sebesar $48,97 \%$ sedangkan sisanya dipengaruhi oleh variabel lain yaitu $51,03 \%$ yang tidak diteliti.

Hasil perhitungan diatas menunjukkan bahwa kualitas pelayanan berpengaruh langsung terhadap citra institusi dengan nilai sebesar 0,2683. Namun secara tidak langsung, kualitas pelayan memiliki pengaruh tidak langsung (melalui kepuasan pemohon) yang lebih kecil dengan nilai sebesar 0.1901. Selanjutnya pengaruh langsung kepuasan pemohon terhadap citra institusi sebesar 0,0313 .

Hasil penelitian ini mendukung hasil penelitian Rafika (2011) uji signifikan simultan (uji-F) menyatakan secara simultan kualitas pelayanan yang terdiri dari dimensi variabel bukti fisik, kehandalan, daya tanggap, jaminan, dan empati secara serempak adalah berpengaruh signifikan terhadap citra merek pada poliklinik RS.

Fandy Tjiptono (2002:126) menyatakan bahwa kepuasan masyarakat merupakan evaluasi purna beli dimana alternatif yang dipilih sekurang-kurangnya sama atau melampaui harapan masyarakat, Kepuasan masyarakat adalah suatu tingkat perasaan masyarakat yang timbul sebagai akibat dari Pelayanan layanan servis yang diperolehnya setelah masyarakat membandingkannya dengan apa yang diharapkannya. Pengukuran kepuasan masyarakat merupakan elemen penting dalam proses evaluasi kinerja dimana tujuan akhir yang hendak dicapai 
adalah menyediakan pelayanan yang lebih baik, lebih efesien, dan lebih efektif berbasis dari kebutuhan masyarakat.

Hasil penelitian ini mendukung hasil penelitian Garnis (2015) yang menunjukan hasil penelitian yaitu kualitas layanan dan citra perusahaan terbukti mempengaruhi tingka kepuasan mahasiswa. Hasil penelitian Sulaeman (2019) menyebutkan bahwa kepuasan pelanggan dapat menyebabkan pelanggan yang loyal yaitu salah satu tujuan akhir dari perusahaan, karena loyalitas pelanggan dapat menjamin kelanggengan hidup perusahaan dalam jangka panjang. Pada dasarnya loyalitas pelanggan didefinisikan sebagai sebuah kesetiaan seseorang terhadap sesuatu hal.

\section{KESIMPULAN}

Berdasarkan identifikasi masalah, hipotesis dan hasil dari penelitian ini maka dapat ditarik beberapa kesimpulan sebagai berikut:

1. Yaitu:

a. Kualitas Pelayanan One Stop Service di kantor imigrasi kelas II Tasikmalaya dengan indikator membangun minat pada pernyataan Pegawai kantor imigrasi kelas II dapat membangun minat masyarakat dalam pembuatan surat perjalanan Republik Indonesia.

b. Kepuasan Pemohon di kantor imigrasi kelas II Tasikmalaya dengan indikator kejelasan petugas pada pernyataan keberadaan dan kejelasan petugas dalam memberikan pelayanan pembuatan surat perjalanan Republik indonesia sesuai dengan jabatanya.

c. Citra institusi Di Kantor Imigrasi Kelas II Tasikmalaya dengan indikator sikap dengan pernyataan menurut anda sebagai pemohon surat perjalanan Republik Indonesia mempunyai keinginan untuk mengeahui citra positif mengenai kantor imigrasi kelas II Tasikmalaya.

2. Kualitas Pelayanan One Stop Service berpengaruh terhadap Kepuasan Pemohon dalam pembuatan Surat Perjalanan Republik Indonesia di Kantor Imigrasi Kelas II Tasikmalaya.

3. Secara parsial dan simultan Kualitas Pelayanan One Stop Service, berpengaruh terhadap Kepuasan Pemohon dalam pembuatan Surat Perjalanan Republik Indonesia dan berdampak terhadap Citra Institusi di Kantor Imigrasi Kelas II Tasikmalaya dalam pembuatan Surat Perjalanan Republik Indonesia. 


\section{DAFTAR PUSTAKA}

Arikunto, 2009, Prosedur Penelitian Suatu Pendekatan Praktik, Rineka Cipta Jakarta.

Barata, Atep. 2004. Dasar- dasar Pelayanan Prima. Jakarta : Elex Media. Komputindo.

Daryanto dan Ismanto. 2014. Konsumen dan Pelayanan Prima. Yogyakarta: Gava Media.

Dwiyanto, Agus. 2014. Mewujudkan Good Governance Melalui Pelayanan Publik. Yogyakarta : Gadjah Mada University Press.

Elistia, 2008, Pengaruh citra Toko, Private Brand, Kualitas Pelayanan terhadap Kepuasan Pelanggan dan Loyalitas pelanggan supermarket, Tesis.

Fahmi Rezha, 2011, Analisis Pengaruh Kualitas pelayanan publik terhadap kepuasan masyarakat ( studi tentang pelayanan Perekam E-KTP dikota Depok), Tesis.

Garnis Anggi Saktiani, 2015, Pengaruh Kualitas Layanan Dan Citra Perusahaan terhadap Kepuasan Pelanggan dan Word of Mouth Di Politeknik Negeri Malang, Jurnal.

Ibrahim, A. (2008). Teori dan Konsep Pelayanan Publik dan Implementasinya. Bandung : Mandar Maju.

Kotler dan Kevin L Keller, 2012. Manajemen Pemasaran Jasa, Edisi Ketiga Belas Jilid Dua, Jakarta : Penerbit Erlangga

Kepmenpan Nomor 63/KEP/M.PAN/7/2003 tentang Pedoman Umum Penyelenggaraan Pelayanan Publik disebutkan tentang prinsip-prinsip pelayanan publik.

,Nomor KEP/25/M/PAN tentang Indeks kepuasan Masyarakat.

Peraturan Pemerintah Republik Indonesia Nomor 31 Tahun 2013 Tentang Peraturan Pelaksanaan Undang - Undang Nomor 6 Tahun 2011 tentang Keimigrasian.

,Nomor 45 Tahun 2014 Tentang Tentang Jenis Dan Tarif Atas Jenis Penerimaan Negara Bukan Pajak Yang Berlaku Pada Departemen Hukum dan Hak Asasi Manusia. 
Ratminto \& Atik Septi Winarsih. 2005. Manajemen Pelayanan (Pengembangan Model Konseptual, Penerapan Citizen's Charter dan Standar Pelayanan Minimal).Yokyakarta : Pustaka Pelajar.

Sulaeman, Maman, 2019. Implementation of GCG In Making Reputation And CRM, Toward Customer Loyality (Case Study At Socials Assurance Labour Company Limited Branch East Priangan) https://www.atlantispress.com/proceedings/iclick-18/125913311

Tjiptono, Fandy. 2000. Manajemen Jasa. Yogyakarta: Andi.

,2002. Strategi Pemasaran, Yogyakarta : Penerbit Andi.

,2005, Pemasaran Jasa, Edisi pertama. Malang: Bayu Media Publishing 